\title{
The Future of Islamic Banking in Sultanate of Oman
}

\author{
Soofi Asra Mubeen ${ }^{1}$, Neelufer Aslam Kulkarni ${ }^{1} \&$ Yahya Khamis Al Hussaini ${ }^{1}$ \\ ${ }^{1}$ Department of Management, Waljat College of Applied Science, Muscat, Sultanate of Oman \\ Correspondence: Soofi Asra Mubeen, Department of Management,Waljat College of Applied Sciences, P.O. Box \\ 197, Rusayl, P.C. 124, Muscat, Sultanate of Oman. Tel: 968-9274-6691. E-mail: soofiam@rediffmail.com
}

Received: January 16, 2014

Accepted: February 27, 2014

Online Published: April 25, 2014

doi:10.5539/ijef.v6n5p203

URL: http://dx.doi.org/10.5539/ijef.v6n5p203

\begin{abstract}
The study aims to identify the future of Islamic Banking in Sultanate of Oman. Islamic Banks adhere to the concepts of (Sharia'ah) Islamic law. The basic source of shariah principles are the Holy Quran which are followed by the consensus of the jurisits and interpreters of Islamic law. The shariah prohibits dealing with interest (Riba) in any shape or form which is the most essential feature of Islamic Banking. The study identified the phenomena related to future of Islamic Banking, Customer's attitudes of Islamic Banking and the effect of Islamic Banking on economy of Oman. Descriptive research design was adopted and proportionate stratified random sampling was chosen for study. The strata were mutually exclusive. Questionnaires on the future of Islamic Banking in sultanate of Oman were distributed among customers and economist in Muscat, Sultanate of Oman. Eighty questionnaires were received from the respondents (customers) and twenty four questionnaires were received from the Economist. Data were refined, tabulated and analyzed. Result indicated that the respondents showed a positive attitude towards dealing with Islamic banking and it supports the national economy.
\end{abstract}

Keywords: customers, descriptive statistics, economist, Islamic banking, Oman, Riba (interest), Shariah (Islamic law)

\section{Introduction}

Islamic Banking is banking based on Islamic law (Shariah). It follows the Islamic rules and practices primarily from the Holy Quran and secondarily from the opinions collectively agreed among shariah scholars. The shariah board is a key element of the structure of an Islamic financial institution, carrying the responsibility of ensuring that all products and services offered by that institutions are fully compliant with the principles of shariah law. Shariah law is derived from Quran and the sunna. The decision to license the provision of Islamic Banking services in Sultanate of Oman have been announced in 2011. The Islamic banking is expected to experience a rapid growth. The main objectives of this decision were to create a stable Islamic finance industry offering credible banking proposition that complies with international best practices, protects customers, and reflects Shari'ah. All listed Omani banks have announced their interest in setting up Islamic Windows. In addition to this, Islamic Banking licenses were granted to two new entities in Oman who aim to operate solely in the Islamic Banking space i.e., Bank Nizwa and Alizz Islamic Bank.

This study examines the future of Islamic banking in Oman and the customer's attitude towards these banks, as well as the value that these banks would add to the Omani economy.

\section{Theoretical Concepts}

Islamic Banking is a banking activity that is consistent with the principles of Sharia and its practical application through the development of Islamic economics. 'Islamic Banking is Sharia complaint finance'. Interest (Riba) is prohibited by Sharia Law under Islamic principles, regardless of whether it is being paid or received.

Oman Banking Sector: The Oman banking sector consists of Commercial banks, specialized banks, non bank finance and leasing companies and money exchange companies which operates under the licensing and regulation of the Central Bank of Oman. The commercial banks dominate the financial sector in Sultanate of Oman.

Islamic Banking in Oman: His Majesty Sultan Qaboos Bin Said has approved the establishment of Islamic Bank in the Sultanate of Oman. The Oman cabinet announced the decision to permit opening of an Islamic bank and 
Islamic windows at local banks as allowed by his Majesty. Oman is the last and the sixth member of GCC to enter the Islamic Banking Business. The Central Bank of Oman has drafted a regulatory framework for Islamic Banking which brings clarity to financial institutions in the market.

Table 1. Islamic banks in Oman as at 30 March 2013

\begin{tabular}{cll}
\hline Number & Name of the bank & Types \\
\hline $\mathbf{1}$ & Bank Nizwa & Islamic banks \\
$\mathbf{2}$ & Alizz Islamic Bank & Islamic banks \\
$\mathbf{3}$ & (Alhalal) Alahli bank & Islamic windows \\
$\mathbf{4}$ & ( Muzn ) Bank Dohfar & Islamic windows \\
$\mathbf{5}$ & (Meethaq ) Bank Muscat & Islamic windows \\
$\mathbf{6}$ & (Misarah ) National Bank of Oman & Islamic windows \\
\hline
\end{tabular}

Source: Central Bank of Oman-CBO Quarterly Statistical Bulletin-December 2012.

Table 2. Islamic banking product

\begin{tabular}{|c|c|c|}
\hline $\begin{array}{l}\text { Islamic banking } \\
\text { product }\end{array}$ & Definition & $\begin{array}{l}\text { The product in } \\
\text { commercial bank }\end{array}$ \\
\hline Mudaraba & $\begin{array}{l}\text { Agreement between two parties where by one party (rab al maal) } \\
\text { provides funds and the second party (mudarib) invests in a specific } \\
\text { Shari' a compliant enterprise or activity for a share in the profits }\end{array}$ & Finance by way of trust \\
\hline Murabaha & $\begin{array}{l}\text { Agreement whereby a party (the bank) sells to the customer a } \\
\text { commodity or asset which it has purchased based on a promise from the } \\
\text { customer to buy the item on specific terms and conditions. }\end{array}$ & Cost-plus financing \\
\hline Musharaka & $\begin{array}{l}\text { Agreement between two (or more) parties to contribute to a particular } \\
\text { investment enterprise, existing or new, or to the ownership of a property } \\
\text { either permanently ('constant' musharaka) or under a diminishing } \\
\text { arrangement resulting ultimately with the customer acquiring full } \\
\text { ownership ('diminishing musharaka') }\end{array}$ & Partnership \\
\hline Sukuk & $\begin{array}{l}\text { Asset backed security where the ownership of tangible assets is divided } \\
\text { into units of equal value and securities issued as per value }\end{array}$ & Participation securities \\
\hline Salam & $\begin{array}{l}\text { Contract is an agreement for advance payment in exchange for goods to } \\
\text { be delivered at a future date. }\end{array}$ & Advance purchase \\
\hline Istisna'a & $\begin{array}{l}\text { Agreement between the bank and a customer whereby the bank sells to } \\
\text { the customer a developed property according to agree upon } \\
\text { specifications }\end{array}$ & $\begin{array}{l}\text { Commissioned } \\
\text { manufacture }\end{array}$ \\
\hline
\end{tabular}

Source: Bank Nizwa-Prospectus Report, 2012.

\section{Literature Review}

Review of literature was done to report the studies related to Islamic Banks. Following studies examined the underlying phenomena of Islamic Banking in various countries. Review provided a foundation to identify the research gap for the present study.

Rammal and Zurbrugg (2007) analyzed the awareness of profit-and-loss sharing financial instruments among 300 Australian Muslims to know the willingness of respondents to purchase profit-and-loss sharing Islamic banking products. The results indicate that the majority of the Australian Muslim population sample would be willing to purchase Islamic banking products, but are not properly informed about profit-and-loss sharing instruments. The results further hint towards a lack of understanding of the principles of Islamic finance. Ahmad (2008) investigated the opportunities and challenges of Islamic banking in United Kingdom with a nine in depth interviews with three different groups of people such as banking authorities, customers of Islamic banking and non customers of Islamic banking and the result revealed that Islamic banking is facing some challenges in UK because the financial system is more favorable to conventional banking and there is a greater opportunities in UK for the development and growth of Islamic financial system because Muslim community is eager to take financial products as they are willing to spend their lives according to their religion. Pawandeep (2008) made a study on future potential of Islamic Banking in India which is the third largest muslim populated country in the 
world. The study identified the significant challenges to materialize the objective of expansion of Islamic banking in India. the product trends are positive in India. Soumik (2008) examined the reasons for working of Islamic financial institutions and start of Islamic banking in India and discussed the changes which is required in regulation and other obstacles of Islamic banking in India. Wilson (2009) evaluates the development of Islamic banking in the GCC. An examination is made to the extent of which government policy, through both legislation and regulation, has facilitated the development of Islamic finance. Shariah governance systems are appraised, in particular the working of the devolved form of self governance by Islamic financial institutions. The deposit facilities offered by Islamic banks in the GCC were discussed. The Issuance and trading of Islamic sukuk securities were also considered and the role of regions financial centers.

A similar study was conducted by Memon (2007) emphasized the role of Islamic banks as financial intermediaries and the importance of financial intermediation for society. Islamic banking an alternate to interest based banking employed the concept of participation in the enterprise, utilizing the funds at risk on a profit and loss sharing basis. The status of Entrepreneurs in Islamic banking is either of partner or investors who maintains ethical relationship with Islamic banks and are not involved in businesses that are prohibited by the Islamic Law. Khan and Bhatti (2008) highlighted the unprecedented growth of Islamic banking and finance in the contemporary finance world. It draws attention towards the growing number of products, systems, infrastructure and supporting institutions of Islamic banking. The current trends, strength and weakness of Islamic banking has been discussed. Ramzan et al. (2012) analyzed the strength and financial health of the Islamic banks of Pakistan by using AID model. The data of all Islamic banks in Pakistan were gathered and analyzed in order to prove quantitatively through AID model that Islamic banks have shown a remarkable growth as a milestone for future Islamic banking.

Mamun (2011) investigated the perceived prospects and growth potential of Islamic banks in Bangladesh. Findings of this research indicate that there is a demand for interest free banking services from the Sharia abiding users. The survey results illustrate that legal support, interbank money market and linkage with other institutions could improve the prospects for Islamic banks in Bangladesh. The study emphasizes the need to have more institutions providing information on operations and principals of Islamic banking. Ullah and Chowdhury (2013) studied the problems and opportunities of Islamic banks in Bangladesh. The study emphasized the development of an interbank Islamic money market, activation of Shariah supervisory board and enactment of Islamic Banking Act. Further it is stated that Islamic banks should introduce new shariah compliant financial products in line with the Islamic shariah and extension of investment in line with PLS framework especially by constituting consortium or syndication by the Islamic Banks.

Literature related to Future of Islamic Banking was primarily based on the study on Islamic Banking in different countries. Some of the study even focused on some specific financial intermediaries to examine the phenomena and dealing related to the working of Islamic Banks. This study made an attempt to study the Future of Islamic Banking in Sultanate of Oman.

\section{Significance of the Study}

The study focused on the future of Islamic Banking to analyze the results and its relationship in banking organization in Sultanate of Oman. Islamic Banking takes into consideration the needs and preferences of Muslim Clients, who forbid interest based transactions (Shariah-Islamic Law). Muslim clients are concerned about Riba (interest) and they donate their interest received. Islamic finance is growing rapidly due to the demand for shariah complaint products from many Muslim countries, thus representing the expansion of Islamic finance a global phenomenon. The activities which are interest free and do not entails pork, alcohol, firearms, gambling are permitted in Islamic finance. The study covers the customers of Islamic Banks and the economist in the Sultanate of Oman. This study may help the Islamic Banks to initiate some change in its working.

\section{Objectives of the Study}

a. To study the future of Islamic Banking in Sultanate of Oman.

b. To identify the effect of Islamic Banking on National Economy of Sultanate of Oman.

c. To find out the customers attitude towards the Islamic Banking Services.

\section{Hypotheses of the Study}

Ho 1: There is no significant relationship between customers attitude towards Islamic banking.

Ho 2: There is no significant effect on the Oman economy with the opening of Islamic banks.

\section{Scope of the Study}

The study investigates the phenomena related to Future of Islamic Banking in Sultanate of Oman from an 
academic point of view. It identifies the effect of Oman economy through Islamic Banking, the future of Islamic Banking and customer's attitude towards the Islamic Banking in Sultanate of Oman. The study provided a foundation in exploring the future of Islamic Banking which will further help the Banking Sector to create best ideas and draw suitable plans.

\section{Research Methodology}

\subsection{Research Design}

Descriptive Research design was used for this research based on adoption of survey method.

\subsection{Sampling Design}

Proportionate Stratified Random sampling method was adopted for this study. 100 questionnaires were distributed among customers of Islamic Banks and 30 questionnaires were distributed among Economist of Oman.

\subsection{Sample Size}

The Total Sample Size in the present study was 104 which constitute 80 customers of Islamic Banks and 24 Economist of Sultanate of Oman.

\subsection{Sample Unit}

Sample unit consist of Customers of Islamic Banks in Oman and the Economists in the Sultanate of Oman government entities and Islamic banks employees.

\subsection{Data Collection Method(s)}

Both primary and secondary data were used.

Primary data: The data was collected through two self administered Questionnaires for the customers of Islamic Banks and the Economist of Oman.

Secondary data: The data were collected through the following sources:

i. Internal sources.

ii. Journal research articles

iii. Internet.

\section{Data Analysis Method}

The data collected from the sample was analyzed by using descriptive statistics and t-test. For analysis of the data SPSS 19.0 Version is used.

\section{Results and Discussion}

Table 3. Reliability test of questionnaire

\begin{tabular}{ccc}
\hline Questionnaire & Cronbach's Alpha & No. Of items \\
\hline Customers Questionnaire & .731 & 16 \\
Economist Questionnaire & .714 & 18 \\
\hline
\end{tabular}

Cronbach Alpha coefficient has been used to test the reliability. Cronbach alpha coefficient is an indicator of internal consistency of the scale. Robinson and Shaver 1973, suggested that if Alpha is greater than 0.7 it means high reliability and if Alpha is smaller than 0.3 it means low reliability. From table 3 it is revealed that the reliability test of Questionnaire is highly reliable as the Alpha value is greater than 0.7.

Demographic Characteristics of the sample of the respondents are presented in order to get clear information of the sample. 
Table 4. Demographic profile of respondents

Table 4.1. Gender of the respondents

\begin{tabular}{lllll}
\hline \multirow{2}{*}{ Gender } & \multicolumn{2}{c}{ Customers of Islamic Bank } & \multicolumn{2}{c}{ Economist of Oman } \\
& No.Of Respondents & \% of Respondents & No.Of Respondents & \% of Respondents \\
\hline Male & 48 & 60 & 17 & 71 \\
Female & 32 & 40 & 7 & 29 \\
Total & 80 & 100 & 24 & 100 \\
\hline
\end{tabular}

Table 4.1 shows the gender of the respondents $60 \%$ of the customers are male and $40 \%$ are female among the customers of Islamic Bank and $71 \%$ of respondents are male and $29 \%$ are female among the economist of Oman.

Table 4.2. Age of the respondents

\begin{tabular}{lllll}
\hline \multirow{2}{*}{ AGE } & \multicolumn{2}{c}{ Customers of Islamic Bank } & \multicolumn{2}{c}{ Economist of Oman } \\
& No. Of Respondents & $\%$ of Respondents & No. Of Respondents & \% of Respondents \\
\hline $20-30$ & 33 & 41.3 & 4 & 16.7 \\
$31-40$ & 38 & 47.5 & 11 & 45.8 \\
$41-50$ & 9 & 11.3 & 8 & 33.3 \\
$51 \&$ above & 0 & 0 & 1 & 4.2 \\
TOTAL & 80 & 100 & 24 & 100 \\
\hline
\end{tabular}

Table 4.2 revealed the age group of the respondents which shows that majority of the respondents among customers $47.5 \%$ and economist $45.8 \%$ are in the age group of $31-40$ years of age.

Table 4.3. Qualification of respondents

\begin{tabular}{lllll}
\hline \multirow{2}{*}{ Qualification } & \multicolumn{2}{c}{ Customers of Islamic Bank } & \multicolumn{2}{c}{ Economist of Oman } \\
& No. Of Respondents & \% of Respondents & No. Of Respondents & \% of Respondents \\
\hline Diploma & 22 & 27.5 & 2 & 8.3 \\
Bachelors Degree & 33 & 41.25 & 11 & 45.8 \\
Post Graduate Degree & 25 & 31.25 & 11 & 45.8 \\
TOTAL & 80 & 100 & 24 & 100 \\
\hline
\end{tabular}

Table 4.3 showed that majority of the customers of Islamic Bank holds Bachelor's degree $41.25 \%$ and majority of the economist hold Bachelors and Post Graduate degree 45.8\%.

Table 5. Hypothesis testing

Ho1: There is no significant relationship between customers attitude towards Islamic banking.

Table 5.1. Result of t-test regarding customers attitude towards Islamic banking

\begin{tabular}{|c|c|c|c|c|c|c|}
\hline & \multirow{2}{*}{ t-value } & \multirow{2}{*}{ Df } & \multirow{2}{*}{ Sig(2-tailed) } & \multirow{2}{*}{ Result } & \multicolumn{2}{|c|}{$95 \%$ confidence interval of the difference } \\
\hline & & & & & Lower & Upper \\
\hline Attitude & -21.461 & 79 & .000 & $* \mathrm{~S}$ & -1.1759 & -.9763 \\
\hline
\end{tabular}

$* \mathrm{~S}=$ Significant at $5 \%$ level of significance.

Table 5.1 shows the result of t-test which reveals that the customer's attitude towards Islamic banks are significant which means that the customers showed a positive attitude towards Islamic Banking in Oman.

Ho 2: There is no significant effect on the Oman economy with the opening of Islamic banks. 
Table 5.2. Result of t-test regarding Oman economy towards Islamic Banking

\begin{tabular}{lccclcc} 
& t-value & Df & Sig(2-tailed) & Result & $\begin{array}{c}\text { 95\% confidence interval of the difference } \\
\text { Lower }\end{array}$ & Upper \\
\hline Attitude & -10.860 & 23 & .000 & $* S$ & -1.4385 & -.9782 \\
\hline
\end{tabular}

$* \mathrm{~S}=$ Significant at $5 \%$ level of significance.

Table 5.2 shows the result of t-test is significant which implies that the economist believe that opening of Islamic Banks will have a positive impact on Oman economy as a whole. It is concluded that economist showed an affirmative approach towards opening of Islamic Banks in Oman.

Table 6. Response of economist regarding effect of Islamic bank in Oman economy

\begin{tabular}{|c|c|c|c|c|c|c|c|}
\hline \multirow{2}{*}{ SI.No. } & \multirow{2}{*}{ Factors } & \multicolumn{2}{|c|}{ Percentage of Responses } & \multirow[b]{2}{*}{ Neutral } & \multirow[b]{2}{*}{ Disagree } & \multirow[b]{2}{*}{ Strongly Disagree } & \multirow{2}{*}{ Total } \\
\hline & & Strongly Agree & Agree & & & & \\
\hline 1 & $\begin{array}{l}\text { Islamic banks will contribute to } \\
\text { increase the national income }\end{array}$ & $45.8 \%$ & $50.0 \%$ & 0 & $4.2 \%$ & 0 & 100 \\
\hline 2 & $\begin{array}{l}\text { Islamic banks will encourage } \\
\text { investment in Oman }\end{array}$ & $25.0 \%$ & $70.8 \%$ & $4.2 \%$ & 0 & 0 & 100 \\
\hline 3 & $\begin{array}{l}\text { Islamic banks will contribute to the } \\
\text { stability of the financial and monetary } \\
\text { system }\end{array}$ & $41.7 \%$ & $58.3 \%$ & 0 & 0 & 0 & 100 \\
\hline 4 & $\begin{array}{l}\text { Islamic banks will encourage citizens } \\
\text { to savings }\end{array}$ & $25.0 \%$ & $50.0 \%$ & $16.7 \%$ & 0 & $8.3 \%$ & 100 \\
\hline
\end{tabular}

Table 6 depicts that majority of the respondents agreed that Islamic Banks in Oman supports the national economy. 95.8\% of the economist agreed that Islamic Banks will contribute to increase the national income and encourage investment in Oman. $100 \%$ of the economist agreed that Islamic banks will contribute to the stability of the financial and monetary system. $75 \%$ of the economist agreed that Islamic banks will encourage savings among the citizens.

\section{Conclusions}

The study focused on the Future of Islamic Bank in Sultanate of Oman. Study was extended to report the effect of following demographic factors such as gender, age, and qualification of the respondents. The profile of the respondents shows that $48 \%$ are male and $32 \%$ are female among customers of Islamic Banks and $71 \%$ are male and $29 \%$ are female among Economist. It is also found that $47.5 \%$ of customers and $45.8 \%$ of economists are between the age group of 31-40 years. Majority of the respondents among customers $41.25 \%$ are holding bachelors degree and $45.8 \%$ of the economist are bachelors and post graduates.

t-test has been done to know the attitude of customers towards Islamic bank in Oman and the effect on Oman economy with the opening of Islamic Bank and it is stated that there is a significant difference among the customers attitude of Islamic bank and Oman economy in the Sultanate of Oman.

Study concluded that the future of Islamic bank in Oman will achieve great success as the customers have a positive attitude towards the dealings with Islamic bank. It is also revealed from the study that Islamic bank will contribute to the prosperity of the national economy and will contribute to the stability of the financial and monetary system in Sultanate of Oman.

\section{Directions for Future Study}

I. Further study can be done on a large sample size.

II. Comparative study can be done for Commercial banks and Islamic Banks in Sultanate of Oman.

\section{References}

Ahmed, W. (2008). Islamic Banking in the United Kingdom: Opportunities and challenges. Kingston University, London: Kingston Business School.
Khan,
A. A. (2014).
Sharia
Compliant finance.
Retrieved
from http://www.halalmonk.com/ajaz-ahmed-khan-sharia-compliant-finance 
Khan, M. M., \& Bhatti, I. M. (2008). Islamic Banking and finance: On its way to globalization. Managerial Finance, 34(10), 708-725.

Mamun, Z. M. (2011). Prospects and problems of Islamic Banking from banks perspective: A study of Bangladesh. $8^{\text {th }}$ International Conference on Islamic Economics and Finance. Doha, Qatar.

Memon, A. N. (2007). Islamic Banking: Present and future challenges. Journal of Management and Social Sciences, 3(1), 1-10.

Pawandeep. (2008). A dissertation on Islamic Banking in India-A study of future Potential TAPMI.

Ramazan, M., Zahid, A., Hussain, N., Islam, K., Aziz, F., \& Ghazenfer, K. S. (2012). Growth of Islamic Banking in Pakistan by using AID model. International Journal of Business and Social Science, 3(23), 152-164.

Rammal, H. G., \& Zurbrugg, R. (2007). Awareness of Islamic Banking products among muslims: The case of Australia. Journal of Financial Services Marketing, 12(1), 65-74.

Robinson, J. P., \& Shaver, P. R. (1973). Measures of psychological attitudes. In A. Arbor (Ed.), MI: Survey research centre institute for social research. University of Michigan.

Soumik, M. (2008). A dissertation on Islamic Banking in India: What is the future potential. Crisil Young Thought Leader.

Ullah, M. M., \& Chowdhury, A. S. (2013). Prospects of Islamic Banking in Bangladesh. Proceedings of 3rd Asia Pacific Business Research Conference, Kuala Lumpur, Malaysia.

Wilson, R. (2009). The development of Islamic finance in the gulf cooperation council states. Working paper, Kuwait programme on Development, Governance and Globalization in the Gulf States.

\section{Abbreviations}

UK = United Kingdom;

AID $=$ Assets, Investments and Deposits;

PLS $=$ Profit and Loss sharing;

SPSS $=$ Statistical Package for Social Sciences.

\section{Copyrights}

Copyright for this article is retained by the author(s), with first publication rights granted to the journal.

This is an open-access article distributed under the terms and conditions of the Creative Commons Attribution license (http://creativecommons.org/licenses/by/3.0/). 